\title{
Community Service by North Carolina Family Physicians
}

\author{
Adam O. Goldstein, MD, MPH, Diane Calleson, PhD, Peter Curtis, MD, \\ Brian Hemphill, MD, MPH, George Gamble, PhD, Beat Steiner, MD, MPH, and \\ Thomas K. Moore, MD
}

Background: Community service is an integral part of American society. Although Family Medicine advocates community service through community medicine, few data exist on family physicians' involvement in voluntary community service activities or roles as community advocates.

Methods: A questionnaire was mailed to 489 North Carolina family physicians, including a $20 \%$ random sample of those in community practice and all statewide faculty physicians. The survey assessed types and amount of volunteer activity, attitudes toward volunteer work, and factors that support or inhibit participation in community service.

Results: The overall response rate was $54 \%$. Most respondents reported strong interests in community service before medical school and residency, yet few reported any relevant training during medical education. More than $85 \%$ of faculty and community practice family physicians reported participating in volunteer service in the previous year $\mathbf{7 0 . 8}$ mean hours for faculty vs $\mathbf{4 5 . 5}$ mean hours for community practice; $P=.06$ ). Family physicians also reported a wide variety of lifetime volunteer activities (mean number of different faculty physician activities 20.8 vs mean number of different community practice physician activities $16.7, P=.00$ ). Less than $50 \%$ of both physician groups reported that their practice or program publicly supports those performing community service.

Conclusions: The great majority of family physicians in North Carolina regularly participate in one or more volunteer community service activities, frequently without organizational recognition. Data about the scope of service expected by communities and provided by physicians may assist the discipline in clarifying the place of volunteer community service in medical education, promotion guidelines and practice. (J Am Board Fam Pract 2005;18:48-56.)

Philanthropy and community service are integral parts of American society, arising historically from religious beliefs and the gratitude of those who have been able to make a successful life in a new country, combined with present day calls for idealism. ${ }^{1,2}$ Every year, approximately 84 million Americans volunteer in their communities, and the value of their time is approximately $\$ 239$ billion dollars. $^{3}$ The federal government recognizes and fosters this activity in part through funding for the Corporation for National and Community Service programs, including Americorps and the Senior Corps

Submitted, revised, 30 August 2004.

From the Department of Family Medicine, University of North Carolina at Chapel Hill (AOG, DC, PC, BH, GG, BS) and the Department of Family Medicine, Naval Hospital, Jacksonville, Florida (TKM). Address correspondence to: Adam O. Goldstein, MD, Department of Family Medicine, UNC School of Medicine, CB 7595 Manning Drive, Chapel Hill, NC 27599-7595 (e-mail: aog@med.unc.edu). and the creation of the USA Freedom Corps. ${ }^{3,4}$ Recent surveys report that $44 \%$ of the US adult population volunteer with a formal organization, and predictors of volunteer community service include youth experiences, strong religious affiliation, positive motivation, concern for others, higher education, and income. ${ }^{3}$ A 2001 study of volunteer community service in North Carolina found that $58 \%$ of those surveyed had volunteered in the previous year. ${ }^{5}$

In the medical profession, similar historical and current commitments to community service exist. $^{2,6-9}$ In 1988, James E. Davis, a past president of the American Medical Association, advocated for community service to be a hallmark of the medical profession. ${ }^{10} \mathrm{He}$ stated that public attitudes toward the medical profession, in times of disenchantment, would be improved if physicians were actively involved in service-and recommended 4 hours of voluntary work per week. 
Community service in medicine traditionally occurs through: (1) charity medical care-representing uncompensated care given because patients visiting the physician or hospital are unable to pay or charges cannot be collected, (2) free professional services (eg, free clinics) given in settings other than the physician's professional facility, and (3) voluntary community service in professional, civic, youth, and educational organizations outside of or in addition to expected roles (eg, faculty teaching medical students). ${ }^{2,6-9}$

To date, the medical literature does not specify whether volunteer community service is a core value for medical professionals. We know, however, that primary care physicians often form strong links to their communities, and voluntary community service may be an important part of this bond. ${ }^{2,9}$ Despite a tradition of community service and a common but often unspoken belief in its value in medical education, few data exist on US physicians' service involvement in community activities outside of charity medical care. ${ }^{11,12}$ Most research focuses on community medicine as a factor in medical training, retention of rural physicians, and the evolution of community-oriented primary care. ${ }^{13-17}$ Questions regarding the types and volume of volunteer community work; effects of practice location and organizational involvement; or the physician's family structure, life stage, or previous influences have received little attention.

We studied the variety and extent of professional, educational and civic community service provided by family physicians in North Carolina to better understand whether volunteer community service is a core value for family physicians. These data have implications for educating medical students and residents about core community competencies of family medicine and may help policy makers better understand policy options for recruiting and retaining family physicians in communities.

\section{Methods}

We conducted a statewide mail survey to look at specific ways that physicians participate in community service outside of clinical care. For this survey, community service was defined as voluntary service activities outside of the normal physician role. This definition excluded community service related to uncompensated medical care, such as volunteering at a free clinic or giving discounted care in clinical practice, dimensions of service that are intimately tied to clinical care and that have previously been studied.

\section{Sample}

The sample included a total of 489 family physicians, with a random sample of North Carolina community practice family physicians $(\mathrm{n}=300)$ and the total population of faculty family physicians in the state $(\mathrm{n}=189)$, approximately one half of whom are community-based faculty. Separate samples were conducted to allow for meaningful comparisons, in that we hypothesized that significant differences might exist between faculty and community practice family physicians on various community service indicators. We identified community practice physicians from current membership lists of the North Carolina Academy of Family Physicians (NCAFP 2500 members). We obtained lists of faculty from the twelve residency programs in the state by contacting residency program coordinators at each site for lists of full-time faculty. These lists were corroborated with individual family practice department web sites, all of which included comprehensive lists of current faculty. The faculty list was matched to the NCAFP list to eliminate faculty names from the latter.

\section{Questionnaire Development}

The questionnaire sought to obtain specific data on types and volume of service activity, attitudes toward community service, and factors that might support or inhibit participation in community service. The questionnaire derived from a literature review, a working knowledge of the field and a draft set of community service promotion and tenure guidelines developed by 2 of the authors (AOG, PC).

The questionnaire consisted of 4 sections: (1) a series of 16 statements concerning the respondent's past and present experience with community service (such as exposure in medical school, residency training, medical school) as well as statements that described attitudes toward service and the physician's appropriate role, scored on a 5-point Likert scale ranging from "strongly agree" (score of 1 ) to "strongly disagree" (score of 5); (2) a series of 25 questions (9 civic service questions, 4 youth service questions, 8 educational/professional service questions, and 4 advocacy/lobbying questions) regarding the scope of community service, with response 
variables of "have done in the past 2 years," "have done in my career but not in the past 2 years," and "have never done"; (3) a series of 8 questions regarding perceived influences that make the respondent more or less likely to perform community service, scored on a 5-point Likert scale ranging from "more likely to perform service" (score of 1) to "less likely to perform service" (score of 5); and (4) a series of personal demographic questions, including participation in service opportunities such as the National Health Service Corps.

To determine a spectrum of community service activities (civic, youth, educational/professional, advocacy/lobbying), we created separate variables for the response variables mentioned above (score $=$ 0 for not having done activity in specified time frame and score $=1$ for having done activity in specified time frame). Within and across service categories, we added up scores to define the range of volunteer service activities respondents reported conducting in the previous 2 years and across their lifetime. Scores for civic service ranged from 0 to 9 , youth from 0 to 4 , educational/professional from 0 to 8 , and advocacy/lobbying from 0 to 4 . Total scores across all 4 service dimensions ranged from 0 to 25 . The survey was pilot-tested with 10 physicians (5 faculty and 5 community practice) and revised based on their feedback.

\section{Data Collection and Analysis}

The questionnaire was mailed to the sample, followed by a mailed reminder card, and a second questionnaire and additional reminder 1 month later to nonrespondents. Returned questionnaires were entered into Microsoft Excel and imported into SPSS (version 11; SPSS Inc., Chicago, IL) for subsequent analysis. Of the 194 faculty questionnaires sent, 5 were discarded because the respondent indicated that they were not a family physician or the potential respondent was no longer available. Of the remaining 189 questionnaires, 121 were returned completed, for a response rate of $64 \%$. Of the 300 community practice questionnaires sent, 145 were returned, for a response rate of $48 \%$.

Descriptive analyses were undertaken separately for the 2 sets of responding physicians. $\chi^{2}$ and $t$ test analyses were conducted to determine differences in the sample's responses to the main research questions, with $P<.05$ deemed statistically significant. The Medical School IRB at the UNC School of Medicine approved the study research methods.

\section{Results \\ Demographics}

The demographic characteristics of the family physicians are shown in Table 1 . The majority were male, white, had spouses working outside the home, had significant debt on leaving medical school, and had attended a public medical school. Compared with faculty, community practice physicians worked in urban locations less frequently $(P=.00)$, had practiced more years $(P=.02)$, and spent a greater proportion of their professional time in direct patient care.

\section{Experiences in Community Service}

The great majority of faculty and community practice family physicians reported participating in community service activities in the previous year (Table 1). Faculty reported a greater mean number of lifetime volunteer activities than community practice physicians $(P=.00)$, a greater number of activities within the previous 2 years $(P=.00)$ and tended to report greater mean hours of service within the previous year $(P=.06)$. Only $7 \%$ of faculty family physicians and $19 \%$ of community practice physicians reported no community service hours in the previous year.

Family physicians reported more service experiences with US service organizations (45.8\% faculty vs $23.8 \%$ community practice; $P=.00$ ) than overseas service programs (21.8\% faculty vs $12.4 \%$ community practice; $P=.05)$. Faculty family physicians agreed significantly more often than community practice family physicians that their colleagues were active in community service activities (60.3\% vs $37.1 \% ; P=.00)$. Less than $10 \%$ of family physicians had received charity or community services during their upbringing, participated in a medical service fraternity in medical school, or participated in programs like the Peace Corps (data not shown).

\section{Education on Community Service and Role Models on Service Participation}

Respondent experiences with community service before finishing training are displayed in Table 2. Overall, whereas $53 \%$ of respondents indicated that they had a strong interest in community service before entering medical school, only $40 \%$ indicated that community service was encouraged in medical school. Compared with commu- 


\begin{tabular}{|c|c|c|c|}
\hline Variable & $\begin{array}{l}\text { Community Practice } \\
(\mathrm{n}=145)\end{array}$ & $\begin{array}{l}\text { Faculty } \\
(\mathrm{n}=121)\end{array}$ & $P$ value \\
\hline Age in years (mean) & 44.4 & 44.4 & 0.99 \\
\hline $\begin{array}{c}\text { Sex }(\%) \\
\text { Male } \\
\text { Female }\end{array}$ & $\begin{array}{l}69.7 \\
29.7\end{array}$ & $\begin{array}{l}61.2 \\
38.8\end{array}$ & 0.16 \\
\hline $\begin{array}{l}\text { Race }(\%) \\
\text { White } \\
\text { African American } \\
\text { Hispanic } \\
\text { Asian } \\
\text { Other }\end{array}$ & $\begin{array}{r}80.3 \\
10.6 \\
2.8 \\
6.3\end{array}$ & $\begin{array}{r}85.8 \\
4.2 \\
0.8 \\
4.2 \\
5.0\end{array}$ & 0.01 \\
\hline $\begin{array}{l}\text { Work status }(\%) \\
\text { Full-time } \\
\text { Part-time }\end{array}$ & $\begin{array}{l}84.1 \\
15.9\end{array}$ & $\begin{array}{l}87.5 \\
12.5\end{array}$ & 0.28 \\
\hline $\begin{array}{l}\text { Practice location (\%) } \\
\text { Urban } \\
\text { Suburban } \\
\text { Rural }\end{array}$ & $\begin{array}{l}25.7 \\
40.0 \\
34.3\end{array}$ & $\begin{array}{l}50.0 \\
35.6 \\
14.4\end{array}$ & 0.00 \\
\hline $\begin{array}{l}\text { Type of medical school attended (\%) } \\
\text { Public } \\
\text { Private }\end{array}$ & $\begin{array}{l}68.3 \\
31.7\end{array}$ & $\begin{array}{l}60.5 \\
39.5\end{array}$ & 0.12 \\
\hline $\begin{array}{l}\text { Percentage of work in direct care to patients }(1,0-24 \% ; 2 \text {, } \\
\quad 25-49 \% ; 3,50-74 \% ; 4,75-100 \%)\end{array}$ & 3.86 & 2.52 & 0.00 \\
\hline Time to drive from home to office (minutes) & 17.5 & 18.1 & 0.71 \\
\hline Years in current practice (mean) & 11.5 & 7.6 & 0.02 \\
\hline $\begin{array}{l}\text { Spouse working outside of home (\%) } \\
\text { Yes } \\
\text { No } \\
\text { N/A }\end{array}$ & $\begin{array}{r}57.9 \\
33.8 \\
6.9\end{array}$ & $\begin{array}{l}67.5 \\
21.7 \\
10.8\end{array}$ & 0.13 \\
\hline Number of children younger than age 10 (mean) & 1.8 & 1.7 & 0.14 \\
\hline Approximate debt load upon finishing medical school (\$) & 36,295 & 27,095 & 0.07 \\
\hline Hours of community service within last year (mean) & 45.5 & 70.8 & 0.06 \\
\hline Number of volunteer activities last 2 years (mean) & 5.8 & 7.7 & 0.00 \\
\hline Number of lifetime volunteer activities (mean) & 16.7 & 20.8 & 0.00 \\
\hline
\end{tabular}

nity practice physicians, significantly fewer faculty physicians reported receiving training in service in medical school $(P=.02)$. Less than $40 \%$ reported formal training in community service during residency.

When identifying role models who had positively influenced their decision to perform community service, the most frequent role models identified were parents $(>60 \%)$ (Table 2). Spouses and spiritual leaders were identified as positive role models by more than $50 \%$ of respondents. Faculty family physicians identified physician role modeling of service as a positive influence significantly more often than community practice physicians $(P=.00)$.

Whereas one half of family physicians agreed that community service contributes to the prestige of the practice, only one third agreed that the practice publicly supports those performing service or that it is a recruiting tool for the practice (data not shown). Faculty family physicians agreed significantly more often than community practice family physicians that their practice or program publicly supports those performing community service $(44.1 \%$ vs $21.6 \% ; P=.00)$. Two thirds of faculty family physicians $(67.5 \%)$ reported that the mission statement of their program includes community service (same question not asked to community sample) (data not shown).

\section{Types of Volunteer Service}

Civic Service

The most frequently reported civic community services within the previous 2 years were giving talks on health-related or other topics to community groups; working with community groups on local health or nonhealth issues; and participating in local health events (Table 3). Giving talks to com- 
Table 2. Educational Experience and Role Modeling in Community Service by Community Practice and Faculty Family Physicians $(\mathrm{N}=266)$

\begin{tabular}{|c|c|c|c|}
\hline & \multicolumn{3}{|c|}{ \% Agree/Strongly Agree } \\
\hline & $\begin{array}{l}\text { Community Practice } \\
\qquad(\mathrm{n}=145)\end{array}$ & $\begin{array}{c}\text { Faculty } \\
(\mathrm{n}=121)\end{array}$ & $P$ value \\
\hline \multicolumn{4}{|l|}{ Educational Experience } \\
\hline I had strong interests in community service before medical school & 51.7 & 55.4 & 0.55 \\
\hline My medical school encouraged me to perform community service & 41.0 & 38.9 & 0.76 \\
\hline My medical school included training in community service & 36.4 & 22.5 & 0.02 \\
\hline My residency encouraged me to perform community service & 36.6 & 50.0 & 0.02 \\
\hline My residency included training in community service & 37.9 & 35.8 & 0.98 \\
\hline \multicolumn{4}{|l|}{ Role Modeling Promoting the Value of Community Service } \\
\hline Parents & 68.9 & 58.4 & 0.08 \\
\hline Church, religious or spiritual leaders & 55.6 & 53.2 & 0.71 \\
\hline Spouse & 53.8 & 57.3 & 0.60 \\
\hline Friends or peers & 52.9 & 64.9 & 0.14 \\
\hline Own children & 48.6 & 47.8 & 0.89 \\
\hline Other physicians & 45.4 & 64.6 & 0.00 \\
\hline Local figures or community leaders & 43.5 & 39.6 & 0.54 \\
\hline Siblings and other relatives & 36.0 & 35.5 & 0.94 \\
\hline
\end{tabular}

munity groups was the only civic service category in which more than $50 \%$ of both groups of physicians reported involvement in the previous 2 years. Faculty family physicians reported significantly more involvement than community practice family physicians in serving on boards of directors of service organizations, working programmatically on health or nonhealth issues, and receiving grants for service-related activities. Community practice family physicians were more involved in civic club activities. Overall, the mean number of reported lifetime civic volunteer categories was greater than 4 for both groups of physicians (mean lifetime faculty civic activities 5.1 vs mean lifetime community practice civic activities $4.5 ; P=.02$ ).

\section{Youth and School Service}

Reports on family physician community service time with youth within the previous 2 years are shown in Table 4. Nearly one quarter mentored school students, whereas smaller percentages served as a school team physician, coached children's sports, or led youth organizations. There was no difference in lifetime youth community service categories between the 2 family physician groups (mean 1.8 vs $1.6 ; P=.76$ ).

\section{Professional and Educational Service}

The great majority of all respondents reported participating in one or more professional organiza-

Table 3. Volunteer Civic Service Activities by Community Practice and Faculty Family Physicians $(\mathrm{N}=266)$ within Last 2 Years

\begin{tabular}{|c|c|c|c|}
\hline \multirow[b]{2}{*}{ Civic Activities } & \multicolumn{3}{|c|}{$\%$ Participating } \\
\hline & $\begin{array}{l}\text { Community Practice } \\
\quad(\mathrm{n}=145)\end{array}$ & $\begin{array}{l}\text { Faculty } \\
(\mathrm{n}=121)\end{array}$ & $P$ value \\
\hline $\begin{array}{l}\text { Giving health-related or other talks to community groups (students, scouts, } \\
\text { Rotarians, church groups) }\end{array}$ & 57.2 & 63.6 & 0.29 \\
\hline Working with community group on local health or nonhealth problem & 47.6 & 60.3 & 0.04 \\
\hline Participating in a health fair or local health/crisis hotline & 38.6 & 37.2 & 0.91 \\
\hline Serving on board of directors of local, state or national service organization & 24.1 & 35.5 & 0.04 \\
\hline Leading a church or other faith-based service program & 22.8 & 21.5 & 0.80 \\
\hline Member of a civic club or society (Kiwanis, Junior League) & 18.6 & 9.1 & 0.02 \\
\hline Working with community group on state or national health or nonhealth problem & 14.5 & 30.6 & 0.00 \\
\hline Serving as an officer of local, state, or national service agency & 13.8 & 10.0 & 0.34 \\
\hline Received grant for service-related activity & 3.5 & 15.7 & 0.00 \\
\hline Lifetime (mean participation) & 4.5 & 5.1 & 0.02 \\
\hline
\end{tabular}


Table 4. Youth/School and Educational/Professional Volunteer Activities by Community Practice and Faculty Family Physicians $(\mathrm{N}=266)$ within Last 2 Years

\begin{tabular}{|c|c|c|c|}
\hline \multirow[b]{2}{*}{ Activities } & \multicolumn{3}{|c|}{$\%$ Participating } \\
\hline & $\begin{array}{l}\text { Community Practice } \\
\qquad(\mathrm{n}=145)\end{array}$ & $\begin{array}{l}\text { Faculty } \\
(\mathrm{n}=121)\end{array}$ & $P$ value \\
\hline \multicolumn{4}{|l|}{ Youth/school volunteer activity } \\
\hline Mentoring students in summer service projects & 20.1 & 23.3 & 0.53 \\
\hline Coaching or sponsoring children's sports team & 15.9 & 8.3 & 0.06 \\
\hline Serving as team physician for school or community sports & 17.4 & 22.5 & 0.30 \\
\hline Leading local youth organization (eg, Boy/Girl Scouts) & 13.9 & 9.2 & 0.23 \\
\hline Lifetime (mean participation) & 1.6 & 1.8 & 0.76 \\
\hline \multicolumn{4}{|l|}{ Educational/profession service activity } \\
\hline Member of one or more professional organizations & 97.9 & 97.4 & 0.81 \\
\hline Teaching medical or other health sciences students & 75.5 & 89.7 & 0.00 \\
\hline Serving on committee of local, state or national health organization & 28.2 & 51.7 & 0.00 \\
\hline $\begin{array}{l}\text { Serving on board of directors for local, state, or national health } \\
\text { organization }\end{array}$ & 12.5 & 30.1 & 0.00 \\
\hline Committee chair of a local, state, or national health organization & 6.3 & 19.8 & 0.00 \\
\hline Serving as elected officer for local, state, or national health organization & 8.4 & 12.9 & 0.25 \\
\hline $\begin{array}{l}\text { Working in international medical service (eg, Doctors Without Borders, } \\
\text { medical missionary) }\end{array}$ & 4.2 & 8.7 & 0.15 \\
\hline Published article in peer-reviewed journal on community service & 0.7 & 7.8 & 0.01 \\
\hline Lifetime (mean participation) & 3.3 & 4.4 & 0.00 \\
\hline
\end{tabular}

tions and teaching health profession students within the previous 2 years (Table 4). Faculty family physicians reported more involvement in educational and professional service activities, such as serving on local, regional, or national committees, and publishing articles relating to community service. Overall, respondents reported voluntary service in more than 3 lifetime professional and educational community service categories (mean faculty family physician lifetime score of 4.4 vs mean community practice family physician lifetime score of $3.3 ; P=.00)$.

\section{Advocacy/Lobbying Service}

The majority of the family physicians reported that they had not participated in advocacy and lobbying activities in the previous 2 years (Table 5). Faculty family physicians reported participating in media interviews and in lobbying officials about community issues more often than community practice physicians. Faculty also reported slightly more lifetime advocacy and lobbying service scores (mean faculty family physician lifetime score 2.0 vs mean community practice family physician lifetime score $1.4 ; P=.00)$.

\section{Discussion}

The current study is one of the few to detail the wide variety of voluntary community services conducted by generalist physicians and the first to describe detailed activities and perspectives of

Table 5. Volunteer Advocacy/Lobbying Service Activities within Last 2 Years by Community Practice and Academic Family Physicians $(\mathrm{N}=266)$

\begin{tabular}{lcc}
\hline & \multicolumn{2}{c}{ \% Participating } \\
\cline { 2 - 3 } Advocacy/lobbying activities & $\begin{array}{c}\text { Community Practice } \\
(\mathrm{n}=145)\end{array}$ & $\begin{array}{c}\text { Faculty } \\
(\mathrm{n}=121)\end{array}$ \\
\hline $\begin{array}{l}\text { Interviewed on radio, television or for local newspaper on community } \\
\text { health or other issues }\end{array}$ & 18.8 & 31.0 \\
$\begin{array}{l}\text { Lobbied government officials on community health or other issues } \\
\begin{array}{l}\text { Wrote a column, op-ed, or letter to editor in local media on a } \\
\quad \text { community health or other issue }\end{array}\end{array}$ \\
$\begin{array}{l}\text { Gave testimony before legislative body (eg, town council) on } \\
\quad \text { community health or other issues }\end{array}$ & 16.0 & 30.4 \\
Lifetime (mean participation) & 9.7 & 13.8 \\
\hline
\end{tabular}


family physicians. Family practice represents the broadest and most intensive community involvement because of its scope of practice. Our study shows that nearly all family physicians reported participating in community service at some time in their professional careers; for most, this was an ongoing activity, suggesting it is a core aspect of their professional lives. Eighty-one percent of the community practice physicians and $93 \%$ of faculty physicians reported involvement with community service in the previous year. The wide scope of service activities reported in the prior 2 years demonstrates the large social investment that most family physicians in North Carolina seem to make in their communities. Their commitment to voluntary service (over and beyond charity and free professional care) is greater than that reported for the general population in a recent North Carolina survey, in which $72 \%$ of the population had given voluntary service at some time in their lives, but only $58 \%$ had provided such service in the previous 12 months. 5

In our study, the mean number of hours of voluntary community service reported by all respondents was 6 hours a month for faculty family physicians and 3.8 hours for community practice family physicians. Excluding those physicians who reported no volunteer service increases the mean number of volunteer service hours per month to 6.4 for faculty physicians and 4.7 for community practitioners. Given an average workweek of 51 hours, the contribution of North Carolina family physicians to voluntary community service clearly meets and may even exceed that in other disciplines. For instance, a Colorado study of pediatricians found that $58 \%$ reported spending 3 to 5 hours a month in past or current involvement in voluntary service work. $^{12}$

Although few benchmarks exists, if volunteer service contributions by family medicine physicians in this study were calculated based on President Bush's exhortation to donate a total of 2 years of voluntary work in a lifetime (under the Citizen Service Act of 2002), then North Carolina family physicians would achieve the Presidential target after 30 years of regular volunteer service, a commitment that spans a professional lifetime.

Differences between faculty and community practice physicians in their voluntary service activities are not unexpected given their disparate job expectations, practice environments and profes- sional goals. For example, teaching is an expected activity for faculty but usually uncompensated for community practice physicians. Faculty family physicians reported greater range and number of volunteer community service activities across civic, professional, and lobbying domains, and they committed more time to leadership aspects of professional organizations. Community practice family physicians seemed to be more active in local community activities and societies. Increased faculty involvement with community service may be related to lower clinical commitments of faculty, who spend about $30 \%$ less time in direct patient care than community practitioners.

The scope of voluntary community service activities by community practice and faculty physicians may have implications for family medicine education. In times of increasing clinical pressures, financial constraints, and bureaucratic overload, there is evidence that community practitioners may diminish both charity care and uncompensated teaching, and this may negatively affect student experiences in primary care. ${ }^{18-22}$ In the past, community practice physicians based charity care on shifting funds acquired from paying patients to nonpaying patients, but this practice is also increasingly untenable given HMO controls and lean budgets. According to the Center for Studying Health System Change, the proportion of physicians providing charity care for the medically indigent fell from $75 \%$ in 1997 to $72 \%$ in $1999 .{ }^{22}$

Leaders in family medicine need to carefully consider whether voluntary community service is purely a personal issue for each physician or a core value of the discipline. If it is recognized as a core value, community preceptors can explicitly demonstrate or model such service to students and residents. Faculty in residency programs, because of their broad involvement with community service combined with their exposure to a wide variety of learners, would also have a substantial role in modeling service behaviors. Yet, questions remain. Would increased role modeling of community service by family physicians stimulate increased interest in the discipline? Can faculty performing extensive community service receive academic tenure and promotion for excellence in community service? $^{23}$

Despite the discipline of family medicine's stated interest in community medicine, most roles played by community practice family physicians in 
providing volunteer community services outside of charity care remain largely unknown. The American Academy of Family Practice and the Society of Teachers in Family Medicine currently offer no formal or written indications in their practice or educational guidelines that family physicians be encouraged or required to become involved in volunteer work beyond their clinical work. More data about the scope of service expected by communities and provided by physicians would assist the discipline in clarifying the place of volunteer community service in medical education and practice.

Relatively small numbers of family physicians reported involvement with lobbying and advocacy activities. It thus might be helpful for family medicine leaders to consider ways of encouraging and expanding family physicians' lobbying and advocacy skills. These skills are particularly needed to advocate for continued Title VII funding, with its positive links to improved health care for underserved populations. ${ }^{24}$

Policy makers with an interest in the recruitment of family physicians in rural and underserved communities know that some aspects of volunteer community service are related to recruitment and retention of physicians, often by building social links. ${ }^{9,15}$ Although the majority of physicians in our study reported that participating in voluntary community service contributed to the prestige of their practice, they reported that the practice infrequently supports or otherwise rewards those involved with such work. Therefore, policy makers and those recruiting health professionals to underserved communities should consider ways of encouraging and supporting the involvement of new physicians in community service. A starting point may be to examine whether voluntary community service is integral to the practice's mission; whether it is written into a mission statement; and how that mission is then operationalized.

Several limitations exist to this research. First, we sampled physicians in only one state and in only one discipline, relying on self-reports of service activities. We cannot estimate possible over- or under-reporting of service activities. We speculate that nonresponders are less likely to be involved with community service, so our findings may represent "best case" data. The response rates for the community sample were significantly less than the faculty sample, reflecting the greater difficulty in getting community practitioners to participate in research surveys. Yet there is no reason to believe that the responding community practitioners were any less likely to overestimate involvement than faculty responders. We also excluded charity and free clinic care from our measurements. Adding charity and free clinic time to volunteer service time reported here would clearly increase the total reported community service.

Those who do volunteer more time are probably motivated by many factors, experiences and role models, of which family and friends seem to be the strongest. Some may perceive voluntary service as a local investment in social capital, a way of building stronger social networks and healthier communities. This invests the physician and his/her family with a personal "return" in terms of respect and social support. ${ }^{25,26}$ Some physicians may believe that they already give enough "at the office."

\section{Conclusions}

If these data represent the range and hours of volunteer community service done by individual family physicians throughout the country, then the discipline is making a substantial contribution to society and their communities over and beyond the clinical care provided. The impact of this work is not easily measured, and it has not been generally recognized as having value in terms of human caring, community functioning, and effects on policy. It is a "hidden" aspect of the health professional's role in society that could even diminish given the stresses and uncertainties in the current health care system.

\section{References}

1. DeTocqueville A. Democracy in America [cited 2004 Apr 5]. Available from: http://xroads.virginia. edu/ $\sim$ HYPER/DETOC/toc_indx.html.

2. Coles R. The call of service. Boston: Houghton Mifflin; 1993.

3. Toppe CM, Kirsch AD, Michel J. Giving and volunteering in the United States findings from a national survey. Washington DC: Independent Sector; 2002.

4. President Bush hails bipartisan introduction of Citizen Service Act [monograph on the Internet]. Washington DC: Corporation for National and Community Service News; 2002 [cited 2004 Apr 7]. Available from: http://www.cns.gov/news/pr/052402. html.

5. Guseh JS, Winders RM. Volunteerism in North Carolina: A survey. Prepared for the North Carolina Commission on Volunteerism and Community Ser- 
vice. Durham (NC): Department of Public Administration, North Carolina Central University; 2001.

6. Lundberg GD, Bodine L. Fifty hours for the poor. JAMA 1987;258:3157.

7. Godkin MA. Community advocacy, physician roles and medical education. Fam Med 1993;25:170-1.

8. Kleinman, LC. Health care in crisis-a proposed role for the individual physician as advocate. JAMA 1991;265:1991-2.

9. Pathman DE, Steiner BD, Williams E, Riggens T. The four community dimensions of primary care. J Fam Pract 1998;36:293-303.

10. Davis JE. Let's work together! A call to America's physicians and the public we serve. JAMA 1988;260: 834-6.

11. Vath, BE, Schneeweiss R. Volunteer physician faculty and the changing face of medicine. West J Med 2001;174:242-6.

12. Brown J, Westrick MC, Rushton FE, Seigal C, LaMont R. Colorado pediatricians' involvement in community activities. West J Med 1995;163:451-3.

13. Kark, SL, Kark E, Abramson JH. In search of innovative approaches to international health. Am J Public Health 1993;83:1533-6.

14. Fulkerson PK, Wang-Cheng R. Community-based faculty: motivation and rewards. Fam Med 1997;29: 105-7.

15. Steiner B, Pathman DE, Jones B, Williams E, Riggens T. Primary care physicians' training and their community involvement. Educ Res Methods 1998; 31:257-62.

16. Plescia M, Konen J, Lincourt A. The state of community medicine training in family practice residency programs. Fam Med 2002;34:177-182.

17. Longlett SK, Phillips DM, Wesley RM. Prevalence of community-oriented primary care knowledge, training, and practice. Fam Med 2002;34:183-9.

18. Barnhill KE, Beitsch LM, Brooks RG. Improving access to care for the underserved. State supported volunteerism as a successful component. Arch Intern Med 2001;161:2177-81.

19. Scott HD, Bell J, Geller S, Thomas M. Physicians helping the underserved: the Reach Out program. JAMA 2000;283:99-104.

20. Cunningham PJ, Grossman JM, St. Peter RF, Lesser CS. Managed care and physicians' provision of charity care. JAMA 1999;281:1087-92.

21. Kemble S. Charity care programs: part of the solution or part of the problem? Public Health Reports 2000;115:419-29.

22. Reed MC, Cunningham PJ, Stoddard JJ. Physicians pulling back from charity care. Issue brief. Cent Stud Health Syst Change 2001;Aug (42):1-4.

23. Vision mission and values statement [monograph on the Internet]. Chapel Hill (NC): University of North Carolina, Department of Family Medicine; 2003 [cited 2004 Nov 18]. Available from: http://www. fammed.unc.edu/Dept/vision.htm.

24. Title VII Funding is associated with more family physicians and more physicians serving the underserved [monograph on the Internet]. Washington DC: The Robert Graham Center; 2002 [cited 2004 Nov 18]. Available from: http://www.graham-center. org/x323.xml

25. Putnam RD. Making democracy work. Civic traditions in modern Italy. Princeton: Princeton University Press; 1993.

26. Putnam RD. Bowling alone. The collapse and revival of American community. New York: Simon and Schuster; 2000. 